\title{
Reservoir Irrigation System Design Based Wireless Sensor Network
}

\author{
M. Zakuan Agung ${ }^{1}$ Eka Susanti $^{1, *}$ R.A Halimatussa'diyah ${ }^{1}$ Susanzefi $^{1}$ \\ ${ }^{I}$ Department of Polytechnic Sriwijaya, Jalan Srijaya Negera, Bukit Besar, Palembang, Indonesia \\ "Corresponding author. Email: ekasusanti@polsri.ac.id
}

\begin{abstract}
The latest development of the robot recently emerged an innovation where the surveillance robot can be controlled remotely via the internet to be more efficient and save time. This innovation is called the Internet of Things or IoT. The Internet of Things has emerged due to technological developments, social, economic and cultural changes that require Any time connection, any things connection, and Any Place connection. Indonesia as an agricultural country makes the agriculture sector the closest sector to its people. Rice is one of the basic needs most commonly consumed by Indonesian people. In the rice industry it is very important to produce good rice to be processed into delicious and fluffier rice. Rice fields that can produce good quality rice are derived from rice fields that are well cared for too. Irrigation Reservoirs and Rice Field Irrigation will be more efficient if done with the help of tools that can work automatically. The Irrigation and Irrigation Irrigation Equipment is equipped with a Humidity Sensor that is able to detect the state of rice fields with three indicators, namely dry moist and wet, so that irrigating rice fields is more efficient. Second, this tool is equipped with a flow sensor so that this tool can calculate how much water passes through the sensor in irrigating rice fields, so that if the amount of water needed for irrigating rice fields is sufficient then the water will automatically stop flowing. And third, this tool is equipped with Wireless Sensor Network (WSN) technology, with this technology the user can monitor data obtained by the device without having to be around the device, so users can operate the device remotely only by using gadget intermediaries such as computers, remote control, handphone and so on. Wireless Sensor Network that is used in reservoirs and irrigation irrigation systems is a wireless network that consists of several components to monitor the condition of a place and can interact with its environment by sensing, controlling and communicating its physical parameters.

Equipped with a humidity sensor (Humidity Sensor) this tool will detect three state of paddy whether the paddy is dry, moist and wet. When the soil moisture value is $<250 \mathrm{Rh}(\%)$, the paddy is dry, while the paddy $>250-500 \mathrm{Rh}(\%)$ the paddy is moist and when the paddy $>500 \mathrm{Rh}(\%)$ the paddy is wet. All three conditions will appear on the LCD and data will be sent to the internet and then a graph will appear.
\end{abstract}

\section{Keywords: Artificial Intelligent, Arduino, Embeded System, Internet of thing, Wireless Sensor Network}

\section{INTRODUCTION}

The water used for conventional reservoirs and irrigation is inefficient because it requires a lot of water and is not as needed. In addition, irrigation reservoirs and conventional irrigation requires considerable time just to irrigate the plants so that they are not effective for large areas, so we need technology that automatically carries out effective and efficient irrigation. Wireless Sensor Network (WSN) is a wireless data communication system that consists of several nodes placed in a particular area. This SSN is implemented into this automatic reservoir and irrigation irrigation system to facilitate data communication over long distances. Each sensor collects data from an area monitor, then send it to the base station (BS). The data transmission used is usually multi-hop, i.e. data is sent from the node to the station (BS).

The sensor used in this WSN consists of 4 Humidity Sensors that function to read the condition or condition of the fields whether dry, moist or wet. And equipped with a Flow Sensor that functions to calculate the amount of water flowing into the fields. This WSN is implemented into this automatic reservoir and irrigation system to facilitate data communication over long distances. 


\section{SUPPORTING THEORY}

\subsection{Arduino Mega 256}

Arduino Mega 2560 is a microcontroller board based on Atmega 2560. Arduino Mega 2560 has 54 digital input / output pins, of which 15 pins can be used as PWM outputs, 16 pins as analog inputs, and 4 pins as UART (serial hardware port), $16 \mathrm{MHz}$ crystal oscillator, USB connection, power jack, ICSP header, and reset button. This is all that is needed to support a microcontroller. Simply connect it to the computer via a USB cable or the power connected to the AC-DC adapter or battery to start activating it. Arduino Mega 2560 is compatible with most shields designed for Arduino Duemilanove or Arduino Diecimila. Arduino Mega 2560 is the latest version which replaces the Arduino Mega version. Arduino Mega 2560 is different from the previous board, because the latest version no longer uses FTDI USB-to-serial driver chip. But, using the Atmega 16U2 chip (Atmega 8U2 on the Revision 1 and Revision 2 boards) programmed as a USB-to-serial converter. Arduino Mega 2560 Revision 2 has an 8W2 HWB line pulling resistor to the Ground, making it easier to put in DFU mode $[1,2,3]$.

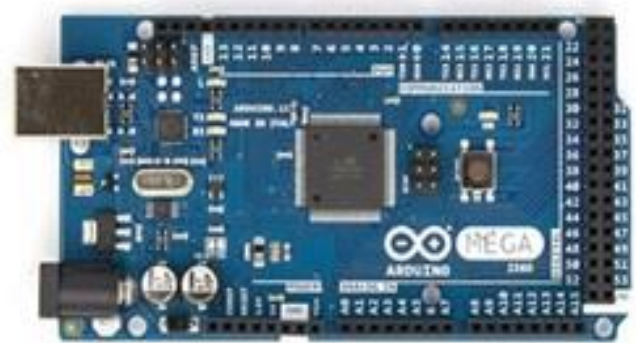

Figure 1 Arduino Mega 256

\subsection{Wireless Sensor Network}

Technological developments increasingly lead to the connectivity of the physical environment. Most observations made in the field involve many factors and parameters to get maximum and accurate results. If researchers want to take information directly in the field, then the obstacle is that it requires a large cost and a long time to detect phenomena that arise, causing inefficient and impractical capabilities. With the existence of WSN technology, it allows researchers to obtain maximum information without having to be in the sensor area. Information can be accessed remotely via gadgets such as laptops, remote devices, servers and so on.

In general, Wireless Sensor Network (WSN) is defined as a type of distributed wireless network, which utilizes Embedded system technology and a set of sensor nodes, to conduct sensor processes, monitoring, sending data, and presenting information to users, through internet communication. Sensors include many types, including humidity, radiation, temperature, pressure, mechanical, movement, vibration, position, and others. Each type of sensor has its own software (application, operating system) and hardware, which will then be integrated and run into the Wireless Sensor Network (WSN) system [4].

\subsection{Water Flow Sensor}

Flowmeter is a tool for measuring the amount or flow rate of water from a fluid flowing in a pipe or open connection. This tool consists of a primary device or referred to as the main device and secondary device or secondary device. Flowmeter generally consists of two parts, namely the main tool and secondary aids. The main tool produces a signal that responds to the flow because the flow rate has been interrupted, while the secondary device receives the signal from the main device and then displays, records, and transmits it as a result of the flow rate.

Soil moisture is the amount of water retained in the soil after excess water is drained. If the soil has high water content, then excess groundwater will be reduced through evaporation, transpiration and underground water transport. Soil moisture can be known through various methods, namely directly through the measurement of differences in soil weight (called the gravimetric method) and indirectly through the measurement of other properties that are closely related to groundwater.

Soil moisture sensor is a sensor that is able to detect the intensity of water in the soil (moisture). The working principle of a soil moisture sensor is to provide an output value in the form of an electric quantity as a result of the water that is in between the sensor capacitor plates $[5,6]$.

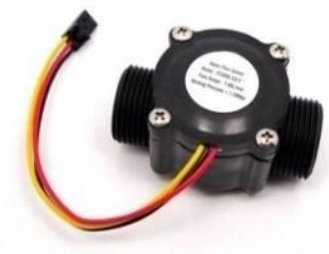

Figure 2 Water Flow Sensor

\section{DESIGN SYSTEM}

This device is a WSN-based reservoir and irrigation system. Each source sensor at WSN will collect data from the monitored area. Then send it to the base station (BS). This tool uses an Arduino Mega 2560 microcontroller as a tool processor. The voltage sent to the processor was ordered microcontroller Arduino Mega 2560 as control of this tool. As an indicator display, this tool uses a $16 \times 2$ LCD. This LCD 
functions to find out whether this tool runs properly according to the commands we made earlier.

After that the controller receives data from the sensor in the form of water intensity information in the monitored area. If the monitored area has a low water intensity or the paddy field is dry with a humidity value of $0-250 \mathrm{Rh}$ $(\%)$, the system will send information and open the valve solenoid valve to send water to the fields and the Flow sensor will read the flow of water flowing downwards the. And when the water intensity is moderate or the condition of the soil is humid, ie with a humidity value of 250-500 Rh (\%), the system will send information and open the valve solenoid to drain the water into the rice fields and the Flow sensor will read the flow of water flowing to rice fields. And if the conditions of the fields are wet or with a humidity value> $500 \mathrm{Rh}(\%)$, the system does not need to drain the water down because it is already wet.

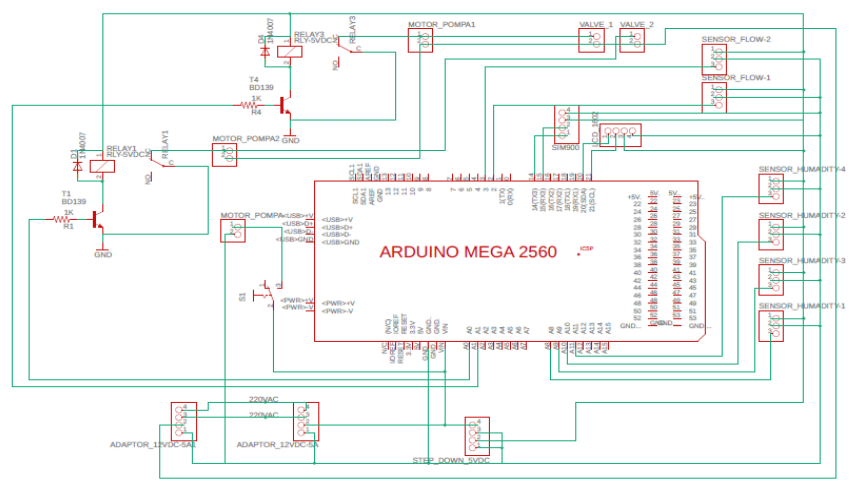

Figure 3 Desain Reservoir Irrigation System Design Based Wireless Sensor Network

\section{CURRENT RESULT}

This humidity sensor is a sensor that detects the intensity of water in the soil. The working principle of this soil moisture sensor, which provides an output value in the form of electrical quantities as a result of the water that is between the sensor capacitor plates. By testing at each test point using a multimeter. As for what was tested on this sensor with 3 Scenario, namely dry, moist and wet.

\section{Scenario 1}

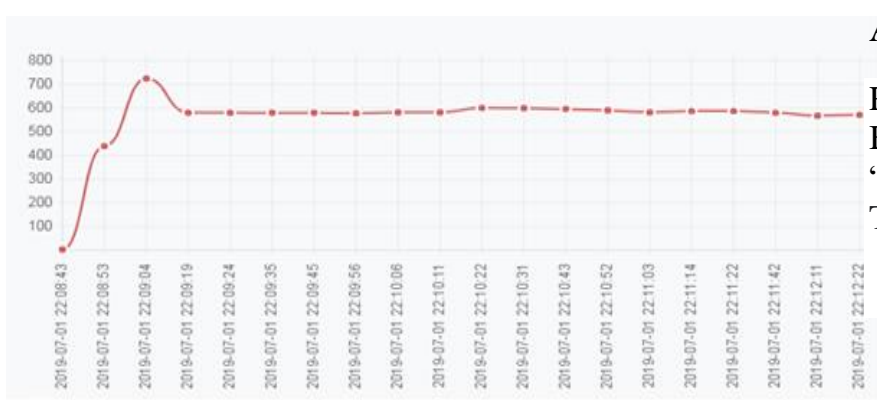

Figure 4 Irrigation Humidity Graph for dry

\section{Scenario 2}

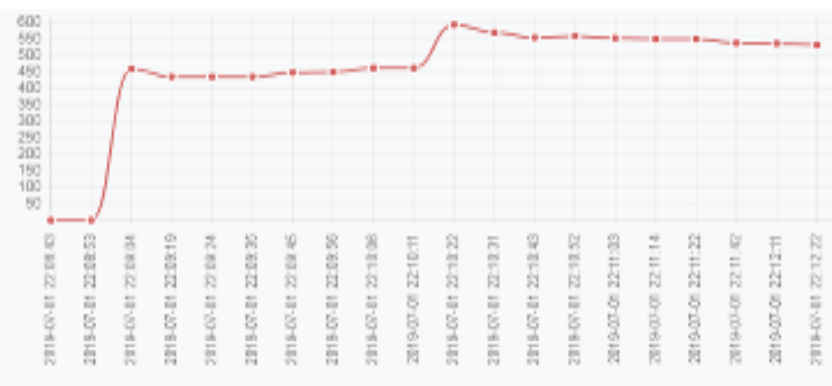

Figure 5 Irrigation Humidity Graph for moist

\section{Scenario 3}

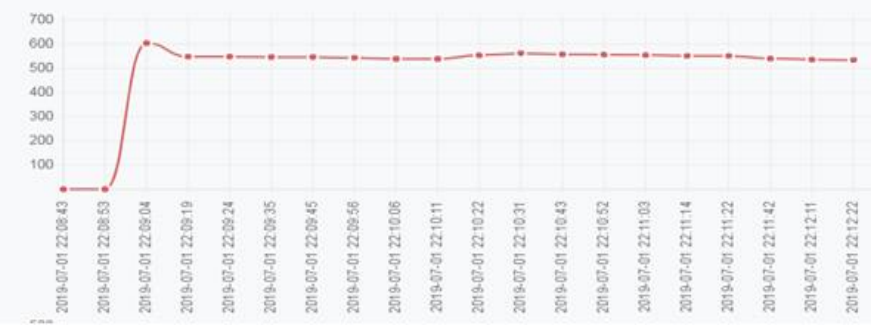

Figure 6 Irrigation Humidity Graph for wet

\section{CONCLUSION}

Wireless Sensor Network that is used in reservoirs and irrigation irrigation systems is a wireless network that consists of several components to monitor the condition of a place and can interact with its environment by sensing, controlling and communicating its physical parameters.

Equipped with a humidity sensor (Humidity Sensor) this tool will detect three state of paddy whether the paddy is dry, moist and wet. When the soil moisture value is $<250 \mathrm{Rh}(\%)$, the paddy is dry, while the paddy $>250$ $500 \mathrm{Rh}(\%)$ the paddy is moist and when the paddy> $500 \mathrm{Rh}(\%)$ the paddy is wet. All three conditions will appear on the LCD and data will be sent to the internet and then a graph will appear.

\section{AUTHORS' CONTRIBUTIONS}

RESERVOIR IRRIGATION SYSTEM DESIGN BASED WIRELESS SENSOR NETWORK "SARJANA" AS A WSN TESTER BY COMPARING THREE SCENARIOS 


\section{ACKNOWLEDGMENTS}

I would like to thank those who have helped a lot in helping this paper. This paper is based on previous research and was developed by the author, for the perfection of the workings of the wireless sensor network. The author also apologizes if there are words that are wrong in taking the sentence, which in this case is the author's reference in making this paper.

\section{REFERENCES}

[1] Adriansyah, Andi dan Hidyatama, Oka. 2013. RANCANG BANGUN PROTOTIPE ELEVATOR MENGGUNAKAN MICROCONTROLLER ARDUINO ATMEGA 328P. Jurnal Teknologi Elektro. 4(3): 102.

[2] Basith, Muhammad Abdul ,2017. PENERAPAN SENSOR ULTRASONIK HC-SRO4 PADA SISTEM PENGUKUR VOLUME PADA MOBIL TANGKI AIR BERSIH. Other thesis, POLITEKNIK NEGERI SRIWIJAYA

[3] Budiharto, Widodo. 2004. Interfacing Komputer dan Mikrokontroler . Jakarta: PT Elex Media Komputindo.Glaser, Horst Albert dan Rossbach,,Sabine. 2011.“The Artificial Human”, Frankfurt
[4]. Eka susanti, Rosita febriani, Sholihin, Eka susanti, Emilia hesti, 2018, The design of hand gesture robot software based on wireless technology, IEEE conferences ICOIACT 2018, Indonesia, p.p 401 406.

[5] Harmalia, Dita. 2015. PENGATURAN OTOMATIS GERAK KAMERA PADA ROBOT PENDETEKSI LOGAM DI AIR TAWAR BERBASIS MIKROKONTROLER ATMEGA 16. Other thesis, Politeknik Negeri Sriwijaya.

[6] Pitowarno, Endra. 2006. Robotika Desain, Kontrol, dan Kecerdasan Buatan. Yogyakarta: Andi

[7] Sholihin, Eka Susanti, "Humanoid Robot Control System Balance Dance Indonesia and Reader Filters Using Complementary Angle Value", E3S Web of Conferences 31, 2018.

[8] Thangavel, D. 2014. Performance Evaluation of MQTT and COAP via a Common Middleware, Singapore.

[9] Waluyo, Yoyo .2015. ROBOT BOAT PENGINTAI BERBASIS ARDUINO DENGAN L293D. Other thesis, Politeknik Negeri Sriwijaya. 